América sin Nombre, n.o 24 (2020): 111-120

DOI 10.14198/AMESN.2020.24-2.10

ISSN: 1577.3442 / eISSN: 1989-9831

Fecha de recepción: 28/05/2019

Fecha de aceptación: 17/06/2019
Modo de citación de este artículo:

VALCÁrCel, Eva. «La ficción de la historia. Teoría y práctica de la novela en Jorge Edwards". La nueva novela latinoamericana sin limites. Lise Segas y Félix Terrones (coordinadores). América sin Nombre, 24 (2020): 111-120, DOI: 10.14198/AMESN.2020.24-2.10

Link para este artículo: http://dx.doi.org/10.14198/AMESN.2020.24-2.10

\title{
La ficción de la historia. Teoría y práctica de la novela en Jorge Edwards
}

\section{The fiction of the story. Theory and practice of the novel in Jorge Edwards}

\author{
Eva VAlCÁrCeL* \\ Universidad de A Coruña
}

\section{Resumen}

La obra literaria de Jorge Edwards sostiene un diálogo constante entre historia y novela. En estas páginas establecemos los fundamentos teóricos de la propuesta estética de Edwards, según la cual historia y novela están hermanadas en la construcción del discurso.

Palabras clave: Jorge Edwards. Memoria. Historia. Novela. Ficción.

\begin{abstract}
Jorge Edwards' literary work maintains a constant dialogue between history and fiction. In these pages we establish the theoretical bases of the Edwards' aesthetics, according to which history and fiction worked closely in the construction of the discourse.
\end{abstract}

Keywords: Jorge Edwards. Memory. History. Novel. Fiction.

\section{La teoría}

La obra narrativa del escritor chileno Jorge Edwards reelabora con frecuencia episodios históricos. $\mathrm{Su}$ escritura se construye a partir de la idea de que lo que denominamos historia ${ }^{1}$ es un material caótico que no existe antes de ser ordenado y transformado en material discursivo. De este modo, la escritura es un elemento necesario y constituyente de la historia con mayúsculas, superando así una evidente

* Profesora Titular de Literatura Hispanoamericana de la Universidad de A Coruña (España). Ha dirigido una decena de tesis doctorales y cinco proyectos de $\mathrm{I}+\mathrm{D}$ sobre vanguardia europea y americana en sus relaciones interartísticas. Es autora de la edición crítica de Los convidados de piedra, de Jorge Edwards (1999) y de monografías como La introducción de las vanguardias en la poesía hispánica (1998), El fulgor o la palabra encarnada (1989), Las revistas literarias (1999). Ha participado como autora y editora en El cuento hispanoamericano del siglo XX (1998), Huidobro Homenaje (1995), Ensayos de literatura hispanoamericana (2005) o El surrealismo y sus derivas (2014). En el año 1996 fue galardonada con la Medalla Gabriela Mistral del Gobierno de Chile.

1. En estas páginas escribimos la palabra "historia» refiriéndonos a la narración y exposición de los acontecimientos pasados y dignos de memoria, sean públicos o privados, según la definición de la Real Academia, frente a «ficción» y «novela» como narración de hechos inventados. El discurso de Edwards sitúa aquí el centro de la discusión. 
función instrumental. La historia es, antes que otra cosa, un discurso creado que no existía antes de serle otorgado un orden determinado, lo que la igualaría a la ficción.

El 14 de abril de 1980, su discurso de ingreso en la Academia Chilena de la Lengua se tituló Mito, Historia y Novela ${ }^{2}$, una elección significativa, definidora de su poética. En este discurso, con el reconocimiento de sus predecesores, Edwards busca una manera propia de ordenar la historia literaria en Chile y, para ello se apoyará en algunas ideas de Roland Barthes ${ }^{3}$.

La legitimidad de la igualación del discurso histórico al novelesco aparece explicada por Barthes después de preguntarse en qué nivel de enunciación habría que situarlo. El discurso histórico tiene un significado que le es inherente en un nivel inmanente, concedido a los hechos por el historiador, y un significado trascendente que reside en el discurso histórico.

Las palabras del escritor explican el efecto del discurso de la historia en el lector, un efecto que aparece como resultado de un juego del narrador:

La relectura moderna de la historia nos permite vislumbrar una paradoja sorprendente. El historiador se concentra y se complace en el llamado «efecto de realidad». Ofrece la seguridad de que lo que narra ha

2. El discurso fue leído el 14 de abril de 1980. Fue publicado ese mismo año en la Colección Biblioteca Nacional de la Academia Chilena de la Lengua. Actualmente está a disposición de los lectores en el portal institucional memoria chilena.cl

3. Edwards cita a Barthes en su discurso: «Roland Barthes (...) escribía que ya no es legítimo anteponer el discurso poético al novelesco, ni tampoco la ficción al relato histórico. Historia y ficción han ingresado al cauce general de la escritura, que exige siempre selección de los materiales, composición e invención» (7). Edwards parece glosar parte de las ideas de Barthes en su ensayo "El efecto de realidad», una lección en la Escuela Práctica de Altos Estudios (1968) y recogido en Lo verosimil (1970). El pensador británico R.G. Collingwood se ocupó, en su libro The Idea of History (1946), de definir el campo de actuación y el alcance de la historia, considerando que la historia debe estar interesada en las acciones humanas; de tal modo que el indagador de la historia debe interiorizar profundamente los acontecimientos hasta tal punto que la elaboración mental que supone la subjetivación enseña al individuo lo que es, a través de los hechos objetivos protagonizados por los otros. Estas ideas parecen formar parte de la intención del narrador de Edwards, en sus preguntas sin respuesta, sus reflexivas dudas asumidas. ocurrido efectivamente y esta sensación es uno de los recursos literarios más seductores para el lector (...) Pero esto no implica que el historiador carezca de libertad para seleccionar sus materiales y para utilizar la estrategia narrativa que más le acomode (11).

El historiador recopila hechos y significantes y los relaciona y organiza para establecer un tejido significativo, convirtiéndose en una elaboración de la imaginación como lo es el discurso literario. El hecho solo puede existir como objeto lingüístico y como parte orgánica de un discurso, aunque se presente como irrefutable y perteneciente a una estructura existente fuera del texto; pero es cierto que no podemos acceder a él desde un espacio exterior al del discurso.

Edwards nos deja esta reflexión en la que compara la supuesta veracidad del historiador con la responsabilidad de la creación, atribuida al escritor:

La concepción tradicional de la historia y de la novela ha pretendido que el historiador está sometido a sus materiales, determinado por los hechos, en tanto que el novelista tendría la libertad suprema de inventarlo todo. La única obligación del historiador sería la veracidad, la fidelidad absoluta a las diferentes voces con que se manifiesta el pasado. El novelista, en cambio, sería un pequeño Dios (10).

En el discurso, en el que Jorge Edwards celebra al historiador chileno Jorge Pereira Salas, el escritor se explica, y en su reflexión se revela su teoría estética que, de diferentes maneras, ha desglosado a lo largo del tiempo en conversaciones, entrevistas o ejercicios narrativos. El discurso de incorporación a la Academia ha de glosar la obra del predecesor, en este caso Pereira Salas, como historiador, le facilitará su reflexión sobre la historia y su discurso y, de manera natural, le llevará a su propio dominio, la ficción; es ahí donde Edwards encuentra el espacio para explicar la idea de la que parte el ejercicio de la hibridación en su obra.

Edwards, en sus palabras, no se reconoce heredero de los historiadores chilenos del XIX que aspiraban a la supresión del yo narrativo, a la objetividad, «una empresa intelectual que por definición es imposible», a la sumisión a una realidad exterior a ellos y que no podía enfrentarse sino con "neutralidad y sumisión». Por el contrario, el yo narrativo, según Edwards, es el que confiere sentido a los hechos por medio de las palabras. La realidad histórica no es exterior al yo narrativo, que ha de traerla a su conciencia y a su 
presente para transformarla en texto, o en obra. La neutralidad es imposible. Edwards escribe la expresión "notarios de la historia» y da a entender que los hechos no se habían seleccionado de antemano por sí mismos, y que el error de los historiadores decimonónicos está en que adoptaron el modelo del historiador francés Adolphe Thiers: «ser simplemente veraz, ser lo que son las cosas mismas, no ser más que ellas, no ser nada sino por ellas, como ellas, lo mismo que ellas» (1). La interpretación de estas palabras nos lleva a un retrato del historiador como ser pasivo, como un narrador enumerativo de batallas, gobiernos y actos legislativos, con un resultado equivalente al de los anales clásicos. Con esta consideración sobre la escritura de la historia, la visión individual que sustenta las narraciones de Edwards, se habría evaporado por la primacía del suceso, más el suceso, más el suceso, en una adición ciega e infinita. Sin embargo, ante esta actitud de afirmada y exhibida neutralidad, sostiene Edwards que esos historiadores chilenos actuaban cumpliendo una misión cívica, mostraban el camino recto, seleccionaban, pues, para mostrar el camino ascensional desde la oscuridad de la colonia hasta el progreso de la emancipación, misión en la que el escritor reconoce una intención docente, aleccionadora, selectiva.

Edwards recuerda que las historias de la conquista y de la colonia exigieron la explicación de sucesos imprevisibles, a menudo inimaginables para los europeos, y necesitaron del efecto iluminador del lenguaje creativo. La conquista del nuevo mundo era una excepcional novela que además estaba ocurriendo delante del escritor. Se trató de una literatura felizmente híbrida, "original», americana, que se sitúa entre la historia y la crónica. El autor se siente continuador de esta obra de cronistas, "género intrínsecamente nuestro", y ajeno a la separación entre la historia y la ficción (3). Y se siente cercano, excepcionalmente, al decimonónico Benjamín Vicuña Mackenna, que en el XIX «abandona el pedestal de nuestra historia republicana (...) (es) el cronista de lo cotidiano y el recopilador de las leyendas tradicionales» (3), a las que incorpora en un lenguaje racional y con una gran distancia, comentarios y guińos al lector.

El papel fundacional de la palabra es traído al centro de este discurso, y es reivindicado apasionadamente por Edwards que se quiere acompañar en esa misión de Ercilla y de Ovalle, además de Valdivia, volviendo a los cronistas, al origen; y llegando a los poetas modernos, a los que denomina «verdaderos recuperadores de ese proyecto de fundar un país por medio de la palabra» contando con el lenguaje de las vanguardias, $\mathrm{y}$ " la experimentación europea». Así reconoce que, en su caso, el descubrimiento de la poesía, de Neruda, Huidobro, Vallejo, Rimbaud, T.S. Eliot o Gabriela Mistral le llevó a elaborar la prosa con el propósito de la exploración a través de la palabra que no tenía un logro previsible, ya que las palabras imponían con su ritmo determinados movimientos conducentes a un sentido imprevisto, al menos en parte. Y este abandono es sentido como una posibilidad de libertad; por una parte la libertad del escritor estaría en las palabras iluminadoras y fundacionales, no en los asuntos y personajes que pueblan su memoria y también, paradójicamente, la del historiador en su relación con los hechos, que es el espacio donde hace su elección. No elige el autor sus temas ni sus personajes, sino que aparecen y pueblan su memoria, recordemos esta idea expuesta por el escritor en relación a su propia experiencia. La experimentación verbal procede de la poesía y es central en su escritura. El lenguaje impone un ritmo, funda una realidad discursiva y según su experiencia, trabajar la prosa, elaborarla, es una exploración en terrenos desconocidos, de resultados no siempre previsibles, porque el lenguaje impone el movimiento, el lenguaje tiene un ritmo autónomo que determina su sentido.

Edwards elige un ejemplo curioso de la obra del historiador glosado, Apuntes para la historia de la cocina chilena; allí Pereira Salas, cuando habla de los vendedores callejeros de comida, construye una frase naturalmente poética y profundamente marcada por el yo, que constituye un ejemplo de la confusión natural de la narración histórica con el lenguaje literario: «Del rescoldo de las tortillas, tortillas buenas, ponía su toque poético, mientras alumbraba la densa noche con su farolito parpadeante»(5). Es este adjetivo el responsable del mestizaje, tortillas buenas; también es el adjetivo que marca el discurso elaborado que no registra únicamente los hechos, el referente, sino que lo ordena y lo matiza, calificándolo: buenas.

Escribe el novelista: «La concepción tradicional de la historia y de la novela ha pretendido que el historiador esté sometido a sus materiales, determinado por los hechos, en tanto que el novelista tendría la libertad de inventarlo todo" (6).

Frente a esta lectura, propone la superación de la división clásica entre novela e historia y una relectura moderna en la que sucede que el historiador, que selecciona sus materiales y su estrategia de narración con una intención de estilo o de moral, se complace en el efecto de realidad que funciona en su favor, 
atrayendo a los lectores interesados por «lo que ocurrió» realmente.

Jorge Edwards citará a Nietzsche para enfatizar su idea sobre la inexistencia de la historia en si misma: «No existen los hechos en sí. Siempre hay que comenzar por introducir un sentido en medio de la anarquía de los hechos. Siempre hay que introducir un sentido para que pueda haber un hecho.»(7) El hecho no surge pues naturalmente terminado para ser reconocido por el autor o el lector. Cuando introducimos ese sentido, inventamos, extraemos el detalle elaborado de la mole de piedra informe, y ya lleva nuestro pulso. El historiador tampoco es inocente, cuando introduce un sentido en los acontecimientos del pasado, los recrea, los reinventa.

En palabras del autor chileno, es el escritor quien, moviéndose en los territorios de su imaginación, de manera involuntaria, es elegido por sus personajes y sus temas y poseído por ellos, por lo tanto no debería ser responsable de sus actos. El historiador es libre en relación a los hechos, con capacidad de otorgarles un sentido, y la libertad del novelista se daría, por el contrario, en el terreno preciso de las palabras iluminadoras y fundacionales, como las palabras de la experimentación poética.

El efecto de realidad es entendido en los historiadores pero con frecuencia traiciona a los novelistas. Ambos inventan, el historiador y el novelista; el novelista posee ciertas imágenes fijas de su memoria y que tienen una cierta autonomía o dinamismo propio, "y se ve enfrentado a cada rato al escepticismo de los que pensaban que Madame Bovary era una seńora de provincia y no una emanación de la fantasía de Flaubert» (7). Por el contrario, el historiador disfruta del efecto de realidad porque, aunque el hecho histórico no tiene existencia fuera de lo lingüístico, según Edwards, el discurso aparenta ser la traslación fiel de otra existencia que sería entendida como la realidad. En el aspecto de la significación, en la narración de hechos articulados en la historia o en la novela, hay indicios que remiten a una idea determinada por un yo; el discurso histórico no puede reunir sino relaciones de hechos. El discurso histórico es esencialmente un imaginario, donde el enunciante de un discurso da vida al sujeto de la enunciación, según Barthes.

En el año 1997, La Casa de América de Madrid dedicó a Edwards una de sus semanas de autor. En una de las sesiones en las que tuve el honor de pude participar, el autor y Mario Vargas Llosa mantuvieron un interesante enfrentamiento dialéctico sobre el carácter de la escritura de la historia frente a la de la ficción. La posición de los dos autores nunca llegará a ser coincidente. El peruano afirma que "Jorge ha dado a la crónica el cuidado, la atención, la minucia artesanal, la pasión y la visión de aliento que los escritores suelen dar a las novelas». Y añade. «la crónica no es puramente creativa, es una reminiscencia de algo que ha ocurrido, la evocación de unos hechos con los que el cronista no suele tomarse las libertades que se toma un novelista $»^{4}$. Para Vargas Llosa la historia y la ficción tienen una diferencia esencial, un «abismo infranqueable entre ambos órdenes». La historia escrita es, en teoría, una descripción fiel de la realidad, la buena literatura no lo es nunca, según el peruano, es siempre infiel, no refleja la realidad que la alimenta.

La argumentación de Vargas Llosa fue escuchada atentamente por Edwards que manifestó su desacuerdo y explicó que no existen diferencias entre la escritura de la historia y la de la ficción, afirmando que los grandes historiadores son grandes artistas, citando a Michelet y su obra La historia de la Revolución francesa "que se lee como si fuera una novela, está escrita como si fuera una novela» (94). Y acudirá nuevamente a Barthes y a su discurso de la historia. El lenguaje del historiador es creativo como el del novelista. Ambos, explica, deben introducir un orden, estructura, andamiaje, también el historiador, ya que su material es esencialmente caótico y no tiene una coherencia estética necesaria para que se reconozca en la lectura como discurso. Y esta reflexión tiene el respaldo del ejemplo de los escritores de los tiempos de la conquista de los que se confiesa Edwards discípulo, como ya hemos dicho.

\section{La práctica}

Jorge Edwards es el autor de Persona non grata (1973), texto que marca un momento crucial en su carrera, y también el de su madurez, como escritor de ficciones relacionadas con la historia. Persona non grata contiene el secreto de la poética de Edwards, algo que queda en segundo plano por la potencia del asunto de la denuncia del régimen de La Habana. Es una novela sin ficción, un testimonio autobiográfico que registra un fragmento de la historia interpretado por el yo. El final de ese libro, nos transmite una idea que estará presente en toda su producción literaria. La obra de Edwards es compasiva, quiere ser justa,

4. La conversación entre los dos novelistas se publicó, transcrita, como el resto de las intervenciones, en Matamoro, Blas. Jorge Edwards (1997). 
busca la verdad; no quiere dividir a los ciudadanos en categorías simples de buenos y malos; busca una visión más profunda que transcienda lo anecdótico.

Edwards se refiere a la clasificación genérica de Persona non grata del siguiente modo:

No es un ensayo sobre Cuba, sino un texto literario, que puede inscribirse dentro del género testimonial y autobiográfico, está más cerca de la novela que de cualquier otra cosa, aun cuando no inventa nada, en el sentido tradicional de la palabra inventar. Solo inventa un modo de contar esta experiencia. Es una novela política sin ficción (338).

La clasificación del crítico Christopher Domínguez Michael (2012) coloca esta obra y otro libro de memorias con Neruda, Adiós Poeta (1990) en el modelo escurridizo de las casi novelas y lo vincula con Truman Capote y Norman Mailer. También David Gallagher (2012) señala que en los textos híbridos de Edwards hay una depuración que no se podría mantener si el autor se mantuviera en el espacio del historiador profesional, obligado a la fidelidad de los hechos, sin marca del yo, y que nuestro autor consigue sostener al unir la biografía singular a la corriente de la historia. Y así procederá Edwards de manera general en sus obras, particularmente en su última etapa, y desde los años 80 (El Anfitrión, 1988) en títulos como El sueño de la historia (2000) La casa de Dostoievsky (2008) y La muerte de Montaigne (2011), introduciendo un espacio para la duda sobre la validez de la clasificación genérica, dejándonos, como lectores, la responsabilidad de denominar novelas a las ficciones que elaboran literariamente la historia. La misma situación la encontramos en el libro Adiós poeta, una memoria de Edwards, pero también una historia de Neruda, en donde las historias conocidas cobran un nuevo valor por el aire nuevo que les da su original elaboración, lo que nos permite profundizar en lo que se cuenta y construir un significado original, una revisión de lo ya sabido. Este modo de proceder como escritor es poco dogmático, tiene una fuerte impronta personalista, individual, tiene visos de forma moral. Puede ser que las cosas hayan sido, puede ser o no; investiguemos y tal vez la complicación brote de la aparente coherencia, de la causalidad hialina, parece decirnos.

En El Sueño de la historia (2000) encontramos un discurso narrativo que presenta tres tipos de narradores con enfoques distintos sobre el mismo asunto y que se contradicen cuando dan su versión. Hay que señalar que el hecho de que el escritor comparezca en su ficción haciéndose notar como narrador de la misma, con dudas razonables sobre los hechos que nos traslada caracteriza especialmente la escritura de Edwards, y así lo citan Viu (2007) con respecto esta novela, y Cruz (2009) refiriéndose a El Inútil de la familia (2004)«...bajo el recurso usado varias veces de 'yo pienso que tú pensaste' o 'imagino que tú hiciste...', el escritor evidencia aquellas zonas grises imposibles de alcanzar por lo que respecta al personaje novelado y su tiempo" (293).

En El Sueño de la historia, el narrador con minúsculas es omnisciente, descriptivo, aparece de vez en cuando intercalando fragmentos históricos. El narrador con mayúsculas tiene nombre, Ignacio, y vuelve a Chile desde el exilio, en 1982; la realidad le asfixia y se evade en la lectura de unos documentos escritos por un historiador, un académico fallecido que deja unos borradores de la historia del arquitecto Joaquín Toesa, que se convertirán en el cuerpo de la novela. Gracias a esta historia privada del arquitecto italiano y su esposa infiel, se construirá ficcionalmente la historia, también privada, del Chile del siglo XviII.

La Casa de Dostoievsky (2008) señala a la vanguardia chilena de los años treinta y al grupo Mandrágora y tiene por protagonista a un Poeta sin más nombre, que parece inspirado en Enrique Lihn. Edwards lo coloca en el centro del texto, pero también en el centro de la Historia, ese poeta es un tal Armando, Ernesto, Eulalio... no sabe quién, no conoce bien el nombre, o el nombre exacto, el nombre del Poeta, es lo de menos, porque él es, a la vez, todos los poetas cuando lo nombra como tal, Poeta, con mayúsculas.

Ese desdén del narrador, esa ignorancia no resuelta, esa duda moderna, engrandece al Poeta, lo hace trascender y lo convierte en una categoría. Esta vuelve a ser una historia en la que el autor se analiza, se ve desde fuera en su radiante juventud, junto a Teófilo Cid, Lucho Oyarzún, El Chico Molina, Enrique Linh, Roberto Matta o Nicanor Parra. Es una pura ficción y a la vez, paradoja, también una autobiografía.

La ignorancia como virtud significa que el narrador no está obligado a responder a todas las preguntas que se plantea, se pone del lado de acá y del lado de allá, escritor y lector; no es un historiador profesional y, para él, ignorar es un rasgo de verdad, como un logro y como un desafío al lector que se ve intimidado, en ocasiones, porque el narrador exhibe con frecuencia su extenso conocimiento del hecho, pero también anuncia que sabe que no sabe más cosas. Lo que leemos entre líneas es que nadie está en lo cierto, porque tal vez no exista la certeza; los historiadores, no conocen toda la verdad, en 
realidad nadie conoce la verdad. Las fuentes de los hechos tienen su propio entramado de incertidumbres, que son los mimbres con los que se construye la ficción y la historia. La verdadera secuencia de los hechos solo es comprobable en una parte objetiva incompleta.

En La muerte de Montaigne (2011), Edwards se convierte en biógrafo ficticio de Michel de Montaigne. En este caso también la biografía del otro lo es también de sí. Se trata de una ficción acompańada por el que la escribe. El narrador nos hace partícipes de su experiencia cuando nos dice que crea una fantasía sobre $m i$ Montaigne, o cuando afirma que el francés significa para mí la lectura y la escritura. David Gallagher habla de una identificación entre Edwards y Montaigne; porque el francés escribe rastreando una verdad o una solución, al menos una que sea propia porque gusta de desmontar las que le vienen dadas, incluso por su razón o por su memoria. En La muerte de Montaigne se ocupa por extenso de la relación entre el ensayista y Marie de Gournay, pero a la vez nos informa de que, en realidad, no conoce la naturaleza de la misma; de ese modo se siente libre para interrogarse sobre las posibilidades que le ofrece la historia y analizarlas según sus intereses. Conocer las respuestas, dominar la historia, la anécdota, los datos, no significa comprender los detalles, el verdadero significado de lo visible, parece explicarnos el narrador ${ }^{5}$.

Parece que el novelista nos ofrece su obra para alcanzar el verdadero conocimiento histórico más allá de las evidencias. Edwards parece referirse a una parte de ese proceso en el que los hechos se nos revelan como resultados de un movimiento humano, de unos acontecimientos que pudiéramos haber protagonizado nosotros mismos, y es así como el historiador propicia un ejercicio de reconocimiento entre los individuos .

\section{El significado de la evidencia. La última hermana (2016)}

La más reciente novela publicada por Edwards, $\mathrm{La}$ última hermana tuvo, durante el proceso de escritura

5. Investigar en las vidas individuales, ser el escritor, «el historiador privado" reza la cita elegida por Edwards para iniciar El peso de la noche; subraya el valor de los casos singulares, minúsculos constituyentes de la historia, que ofrecen el corazón del hecho, es más, posibilitan la existencia del mismo. otros títulos, Retrato de María, La historia de María o Réquiem por una Justa. En ella Edwards vuelve a disfrutar con la Historia y recupera, e inventa a la vez, un episodio bien conocido de la Segunda Guerra Mundial: la ocupación alemana de la ciudad de París. Un asunto nada original en principio, largamente tratado, visualizado, estudiado en múltiples ocasiones, de tal manera que, como hecho histórico, no podemos decir que nos es ajeno. Conocemos la verdad, el hecho histórico, pero el relato de Edwards es radicalmente nuevo; utiliza la sucesión de acontecimientos, el archivo, y lo transforma, nos cuenta aparentemente lo mismo, pero el relato está marcado por el yo del novelista, por su vocación de analista, por su gusto para introducir la duda sobre las verdades fulgurantes en exceso. Edwards elige su atalaya e instaura un orden y nos transmite que nada es verdad todo el tiempo y que exhibir la duda, la ignorancia, es una virtud del que narra.

Como exponía el autor en su discurso ante la Academia chilena, "los asuntos y los personajes lo escogen a uno», y él encontró a la protagonista de su relato, y la reconoció en París. María es un personaje de su familia. Un itinerario casual le llevó a descubrir la historia y a ser elegido por ella. Paseando por el distrito cuarto de París y "frente a las hermosas fachadas de la Isla de San Luis está el museo de la Shoah ${ }^{6}$, allí está la alameda de los Justos, un monumento a los hombres y mujeres que, sin ser judíos, ayudaron y protegieron a los judíos de los nazis. En ese muro encuentra un nombre y un personaje que lo habitará, «Madame Errázuriz con un z de más»; averigua que esa mujer es María Edwards Mac Clure ${ }^{7}$, casada con el Señor Errázuriz y conocida en Francia con el nombre de su primer marido. Los personajes, esas imágenes persistentes, le conducen a preguntarse qué hizo la Señora Errázuriz para estar inscrita en el muro de los Justos de París. Se

6. «Héroes desconocidos» es el título del artículo que Jorge Edwards publicó en El País, el 19 de agosto de 2010, cuando se encontraba en el proceso de investigación para escribir su novela. Las citas entrecomilladas pertenecen al artículo.

7. María se quedó viuda en 1922. Vivía entonces en París y permaneció en la ciudad después del suicidio de su esposo. Durante la ocupación nazi empezó a trabajar en el hospital Rothschild, ligado a la comunidad judía. María salvó a los hijos de los judíos deportados a los campos de concentración, sacando a los recién nacidos bajo su capa de enfermera y entregándolos a la resistencia que les encontraban un hogar. Fue descubierta y torturada por la Gestapo y salvada, a su vez, por la intervención del almirante Wilhelm Cannaris. 
conoce a María por su carácter festivo y mundano, relacionada siempre con la alta sociedad y sus fiestas, de la que se sabe que frecuentaba a la baronesa de Rothschild y que era amiga de la escritora Colette, según se desprende de la dedicatoria que Edwards dice haber encontrado en una biblioteca del Valle Central de Chile: "He seguido una pista y he atado cabos sueltos con curiosidad", escribe sobre la narración de los acontecimientos históricos. Edwards visitó el hospital Rothschild, donde ella trabajó, e inventó una delicada personalidad posible en la que mundano no parezca significar frívolo y despreocupado, colocó a María en una situación en la que tenía que reaccionar, y necesitó escribir el relato de los hechos que permite comprender que una mujer, sin proponérselo primero, se convierta en salvadora de nińos judíos en unas circunstancias de terror, en una heroína accidental.

La narración se inicia en el momento de la entrada de los tanques alemanes en París por el Arco de Triunfo, y el narrador, que no se ocupa en retratar ese avance, ni la formación de las tropas ni su actitud, transmite, por medio de la contenida emoción de su personaje, la atmósfera de guerra parisina:

Los ruidos lejanos, sobre todo si eran motorizados, la desvelaban, le daban la sensación de que el corazón se le iba a parar, de que respirar se había convertido en un esfuerzo abrumador. Pero pronto se olvidaba de todo eso, con una actitud muy suya, en la que intervenían elementos de desaprensión, de seguridad social, de manera de ser personal, de estilo propio, de ingenuidad con respecto a los peligros reales que la amenazaban... (97).

En este dramático contexto, María pide una copa de champán, y podría parecer frívolo, ella lo sabe, pero tiene otro significado, el de la transgresión del orden establecido. El narrador nos informa:

En el Chile de aquellos ańos, los condenados a muerte por la justicia pedían un último deseo... Tomar una copa de champán en el momento más negro era muy de ella... porque era contradictoria, (...)A la vez tenía un corazón encendido al rojo vivo, una brasa ardiente, que no se sometería (13).

Este anuncio revela el carácter de María justificado en su posterior resistencia activa, rescatando recién nacidos debajo de su capa de enfermera, ocultos en un bolsillo interior y sedados, y los entrega a la resistencia para salvarlos. Después estos niños le llamarían tante Marie, y cuando fueron adultos buscaron la manera de homenajearla en el muro de los Justos.
No podemos prejuzgar ni quedarnos con la superficie, parece avisar el narrador. Pero María, que lee a Wilde, a Shakespeare y a Elliot, que es amiga de Vicente Huidobro y de Colette, no sabe muy bien, en su ingenuidad, qué hacen los nazis con los judíos, y encuentra que el metro está limpio, también con los alemanes invadiendo Paris, y eso le lleva a no querer pensar mal de los nazis cuando va camino de su trabajo como voluntaria al hospital judío. El personaje es ingenuo, pero evoluciona radiantemente, guiada por un instinto de bondad, y comprende que ha entrado en una etapa nueva en su vida que no tiene retorno posible; pero al instante en un espacio fronterizo con sus dos personalidades, se ve desde fuera, en su futuro de enfermera voluntaria: "Regresaría del hospital con salpicaduras de sangre en la capa, se cambiaría de ropa con gran rapidez con una visión clara de la blusa y de la joya que deseaba ponerse, del abrigo todavía delgado, del cuello color ladrillo, de botones enormes, y partiría a la casa de la duquesa tal o la baronesa cual» (47).

Esta mujer que niega una de sus alfombras al Mariscal Goering, será torturada por la Gestapo y no hablará. María permanecía en estado de alerta constante, también para contemplarse a sí misma en acción y descubrirse:» Descubría a cada rato posibilidad, recovecos de sí misma, reacciones profundas que no conseguía descifrar... Tenía una sensación de incertidumbre, de perplejidad, pero, miedo, lo que se llama miedo, no se podía decir que tuviera». (119)

El narrador, como esperábamos, cuestiona, se pregunta cómo, declara su incompetencia como historiador:

Toda historia tiene cabos sueltos, desarrollos laterales, orígenes remotos y que al comienzo no eran visibles y así se explican las relaciones de esta chilena más o menos mundana, medio despistada, y a quien, de repente, sin razones aparentes suficientemente claras, le había dado por arriesgar el pellejo para salvar niños (144).

La sabiduría del narrador y su honestidad nos proponen analizar la historia y llegar a nuestras propias conclusiones; sucede así el en caso de Wilhelm Cannaris, personaje histórico y también de la novela, jefe de la marina imperial y hombre clave de la inteligencia nazi que habría traicionado a Hitler y habría participado en la Operación Walkiria, y que murió ahorcado en un campo de concentración de Baviera. 
La historia nos dice que Cannaris ${ }^{8}$ estuvo en Chile en la Primera Guerra Mundial y allí conoció a la familia Edwards, hecho que aparece varias veces en la novela. Su presencia en la narración es muy importante, y en ella se nos acercan varias interpretaciones diferentes de su historia; la de María, la del narrador inseguro, la propia actuación que se le atribuye; varias versiones de su estancia en Chile, de lo que hizo allí y de por qué protege a María. Es un personaje misterioso y rigurosamente histórico del que conocemos circunstancias externas, pero desconocemos la razón de los hechos, y esto es lo que interesa al novelista.

\section{La poesía de la posibilidad. Los fragmentos poéticos prescindibles}

La aportación de la literatura a la historia es especialmente notable en aquellos fragmentos poéticos prescindibles, como hemos decidido llamarlos, de los que Barthes decía que no tenían sitio en la articulación del relato, los que se excluyen del inventario en el análisis porque son superfluos en apariencia y en relación con la estructura del discurso, y no parecen tener una finalidad directa, no computan entre los materiales necesarios para la construcción del relato. Esos rellenos, falsamente prescindibles, tienen un valor extraordinario para nosotros, ya que, desde nuestra lectura de la historia y la ficción, estos fragmentos de lujo, inútiles, nos ofrecen el orden particular que a los hechos de la historia ofrece el escritor de ficciones, nos ofrecen notas, perfumes, colores que hacen posible compartir la experiencia que está construyendo en la ficción; nos conmueven y preparan nuestra sensibilidad sin obligarnos a seguir la voz del narrador para la comprensión de la historia narrada, haciendo que lleguemos a construir nuestra propia emoción, nuestra casi memoria, de la gran historia de María en el poderoso contexto histórico, aún latente en la memoria de Europa, en uno de sus más simbólicos capítulos: la ocupación de París. Más concretamente, son fragmentos que aseguran, por ejemplo, el inicio de esta novela, que transforma la ocupación de París, hecho histórico, en

8. Wilhelm Cannaris (1887-1945) murió ahorcado en 1945 después de haber traicionado a Adolf Hitler y conspirar contra el en la Operación Valkiria. Conoció a la familia Edwards en Chile, en 1915. Viajaba en el crucero alemán Dresden que fue hundido por la marina británica. Huyó con una identidad falsa a través de Argentina. un metafórico y efectivo silencio aterrador salpicado de inarmónicos y amenazantes chirridos metálicos:

Hubo días de un silencio excepcional, que ella no recordaba en todos sus años de París, ni siquiera en sus agostos más solitarios, más extravagantes. Parecía que los pájaros hubieran dejado de cantar, o que hubieran emigrado, escuchando el rechinar de las orugas metálicas, su fuerza aplanadora antes de que los oídos humanos pudieran escucharlas (7).

Escuchar y sentir el miedo y la amenaza. Escuchar también por la vista, interpretar la amenaza en el silencio de los pájaros desaparecidos, multiplica la emoción de la paralización por la angustia de la amenaza de la violencia y la muerte. Silencio, soledad, dolor, muerte silenciosa por aplastamiento; imágenes poéticas que producen un potente efecto de realidad en el momento de la lectura, un efecto que apela al sentimiento más que a la razón; pero que requiere de la inteligencia y la complicidad del lector.

Hay otros casos en los que lo prescindible, el objeto no marcadamente histórico, determina la interpretación por parte del lector de la gran historia narrada. Estos fragmentos determinan la significación del texto, son coherentes con el modelo del narrador, que se permite plantear posibilidades, fantasear; ver los acontecimientos con múltiples ojos.

El narrador entra en el alma de María a través de las palabras que originan la interpretación el paisaje en el contexto de la preocupación de la mujer por esos nuevos tiempos que se acercan, de los que ella, recordando a su amigo Vicente Huidobro,, cree que van a ser el fin de una época, o más aún, el final del tiempo; el fin del mundo, el apocalipsis $Y$ continuará el narrador ayudándonos a interpretar los sentimientos de María, acercándonos el aire del contexto, impregnado de marcas oscuras, de sombras que avanzan lentamente y nublan el espíritu festivo de una mujer, hasta ahora, despreocupada y frívola. El día fue limpio como el acero y cuando decae la luz lo hace de manera inquietante y premonitoria y secreta; cómo transcurre el tiempo vital; y aquí cómo se transforma una ciudad llena de vida en una ciudad tomada por el ejército nazi, sin que decaiga la belleza, que se vuelve trágica por la utilización que de ella se hace.

El atardecer de ese día fue largo, sin nubes, de un azul que fue adquiriendo tonos de acero celeste y contra el cual, como en un telón, se perfilaban los techos, los hermosos techos de París, los árboles, los contrafuertes 
de las plazas, con sus columnas ceremoniales, con sus estatuas, con sus dorados (11).

Pasamos así, en la misma página, de la ciudad viva, monumental y hermosa, recortada como un decorado brillante (acero, celeste pero acero, cielo y luz dura que no proyecta sombras) a una luz robada, a un paisaje urbano en el que en los detalles, las esquinas, los jardines interiores, no son los mismos, y aunque la transición apenas se pudo percibir, el resultado se ha impuesto: «La oscuridad avanzaba con gran lentitud, de manera que no se notaba el avance, pero después, en el suelo, en las esquinas, en los arbustos, en los jardines interiores, en los pilares de los puentes, sí se notaba» (12).

El narrador incluye frecuentemente estos fragmentos que matizan de una manera lejana el discurso, son poco significativos en un principio, poco sustanciales en los derroteros de la gran historia, pero colocan al narrador al lado del lector, son definitivos para que el personaje se explique en su evolución. Las sombras avanzan, reales o imaginadas, transforman el jardín bajo el toque de queda y llevan a la protagonista a preguntarse, en soledad, qué le puede pasar ahora, lo peor, cómo podría ser tan malo si en su jardín:

Las sombras crepusculares ya se habían extendido (...) y las grandes hortensias callaban y se concentraban secretas, en sus rincones. Había un aire fino, fresco, que penetraba en los intersticios, en los de la ropa, del cuerpo(...) No se escuchaban explosiones ni disparos, no había ruido de sirenas en ninguna parte. La calle, en las horas anteriores al toque de queda, estaba casi vacía, fantasmagórica (36).

De nuevo las sombras, no dibujan claramente el peligro, su función es nublar la vida, silenciar las risas, convertir el silencio en rutina; cambiando el antiguo orden e instaurando uno nuevo:

En aquellos días, cuando la ocupación se había consolidado y mucha gente que había huido en el primer instante empezaba a regresar, cuando todo parecía más rutinario, más normal, cuando las calles estaban más tranquilas en medio del relativo silencio, se vislumbraba de repente una sombra, un aviso que provenía de un lugar oscuro, o que anunciaba un encuentro con el abismo (44).

El mal está ahí, pero no se hace presente, no es un frente abierto, una agitación, una lucha; más bien la ocupación se lleva a cabo mientras en las embajadas siguen las conversaciones de sobremesa con el inconveniente relativo de los apagones; como si nadie quisiera darse cuenta de la realidad, actúan como comparsas, dice el narrador, y se pregunta de qué opera o comedia. Nos hace pensar sobre qué y cómo pasaron las cosas, en la complejidad de los acontecimientos de la historia, en las verdades relativas y en las historias internas del decorado parisino. Ese narrador no acusa, no sabe bien, quiere saber, como el lector, y se interna en caminos poco iluminados, aproximándonos a la experiencia de sus personajes.

María percibe con perplejidad el efecto de la ocupación silente; era como si el París que ella amaba hubiera cambiado, sin que ella se hubiera dado cuenta. Lo percibe como un sueño repentino, vago, impredecible:

... un sueño que transcurría adentro de un túnel oscuro, de paredes que exudaban humedad, o como el comienzo de una pesadilla. Los ojos de María van percibiendo paulatinamente la guerra en los detalles, en los grandes nubarrones del horizonte, signos de una tormenta próxima. Pero la noche, a pesar de todo era hermosa, hermosa y terrible, llena de poderes escondidos. En la distancia empezaron a escucharse explosiones, hubo reflectores que buscaban en el cielo, haces de luces que giraban, y resonaron los tiros de la artillería antiaérea (136).

El moderno e inseguro narrador de ficciones históricas, que no juzga definitivamente, resulta original en la escritura de Edwards y se va configurando con matices a través del tiempo y de las obras; este narrador parece haberse reconstruido a partir de las cenizas del clásico y omnipotente narrador omnisciente y cree que lo caricaturesco sería pretender aparentar dominar la ficción y asegurar lo que ha pasado o cómo pasarán los acontecimientos de la ficción, y ¿por qué no? lo que pasará y lo que la memoria nos dice que ha pasado en nuestra propia vida, la vida del lector que se inscribe, por efecto de la lectura, en el mismo tiempo de la ficción del narrador dando lugar a un ejercicio de compasión colectiva que produce una profunda emoción, al analizar los acontecimientos inexplicables de la ocupación nazi de París, de manera general, y en sus detalles. El narrador transmite el dolor por la pérdida sin porqué de una ciudad que se convierte en un decorado tenebroso y también los detalles incomprensibles que esa ocupación traslada a la vida de las personas de cualquier posición. Explica cómo cambia la vida de María y la trasforma 
en otra persona que no sabía que era, pero también la de la Baronesa Rothschild. Pero más cambiarán aún las vidas de las madres judías que son enviadas a campos de exterminio y las de sus hijos, algunos rescatados por la resistencia a través de María Edwards y otros sin espacio en la narración, pero presentes en nuestras mentes y en las de los personajes y el narrador; "Y es que toda historia tiene cabos sueltos, y el escritor tiene la posibilidad de seguirlos, observarlos y convertirlos en algo nuevo, en una obra creada, interpretándolos, rellenándolos, construyéndolos, y sacándolos fuera de los límites de los lugares comunes» (144).

Las novelas de Edwards antes citadas se inscriben en el marco de la ficción histórica, con abundantes pasajes que aluden a la historia oficial, al archivo que solidifica los contenidos orales del mito, según la categorización de González Echevarría (2000). Lo que la historia guarda en el archivo es fragmentario; el historiador y el escritor deben seguir el mismo camino, deben ordenar, seleccionar y rellenar huecos para que el nuevo discurso alcance una verdadera significación.

En la trayectoria ficcional de Edwards se percibe un interés decidido en utilizar contenidos históricos, como lector y admirador de sus predecesores chilenos Alberto Blest Gana y de Victorino Lastarria, avanzados en el realismo de su época costumbrista y decide innovar en el modo de reformular esos contenidos al servicio de una ficción literaria. Es en los años 80, cuando se materializan esas preocupaciones de innovación del chileno, con la aparición de narradores múltiples y originales que sustituyen al narrador tradicional omnisciente que es parodiado y ridiculizado. Las novelas de Edwards reúnen las condiciones para ser incluidas en el conjunto de nuevas novelas históricas hispanoamericanas, si queremos expresarnos en la terminología de Seymour Menton (1993). En este trabajo, puesto que nos hemos ocupado de la propuesta de Edwards sobre la equiparación de la historia y la novela, en cuanto a procedimiento y a resultados, asumimos el imposible conocimiento de la verdad histórica o de la realidad, lo que justifica la ficcionalización de los personajes históricos y la metaficción o los comentarios del narrador sobre el proceso de creación.

\section{Bibliografía}

Barthes, Roland et al. Lo verosimil. Buenos Aires: Editorial Tiempo Contemporáneo, 1970.

Collingwood, Robin George. Idea de la Historia. México: FCE, 2004.

Cruz, Nicolás. (Reseña) Viu, Antonia. Imaginar el pasado, decir el presente. La novela chilena (1985-2003). Historia, 42:1, (2009): 293-296

Domínguez Michael, Christopher. «Jorge Edwards o el arte de la casi novela». Letras libres. México: Editorial Vuelta, 2012.

Edwards, Jorge. Mito, historia y novela. Santiago de Chile: Biblioteca Nacional de la Academia Chilena de la Lengua, 1980.

EDwards, Jorge. «Héroes desconocidos» en El País, 19 de agosto de 2010.

EDWARDs, Jorge. Persona non grata. Barcelona: Tusquets, 1990.

Edwards, Jorge. La Casa de Dostoievsky. Barcelona: Tusquets,2018.

EDWARDs, Jorge. La muerte de Montaigne. Barcelona: Tusquets,2011.

EDWARDS, Jorge. La última hermana. Barcelona: Acantilado, 2016.

Gallagher, David. «Edwards, Montaigne y los géneros híbridos». Estudios Públicos. Santiago de Chile: CEP, (2012): 192-212.

González EcheVarría, Roberto. Mito y archivo. Una teoría de la novela latinoamericana. México: FCE, 2000.

Matamoro, Blas, ed. Jorge Edwards. Madrid: Ediciones de Cultura Hispánica, 1988.

Menton, Seymur. La nueva novela histórica de América Latina. México: FCE, 1993.

VIU, Antonia. Imaginar el pasado, decir el presente. La novela chilena (1985-2003). Santiago de Chile. Ril Editores, 2007.

9. El autor considera que la historia, los cambios en las estructuras sociales, han sido responsables de la evolución formal de la novela latinoamericana, por encima de la influencia de los modelos literarios anteriores. 